\title{
Toward Establishing Entrepreneurship Education and Training Programmes in a Multinational Arab University
}

\author{
Abbas Abdelkarim \\ Correspondence: Abbas Abdelkarim, Formerly, Arab Open University, Qatar. E-mail: abbas.a.k.ahmed@ gmail.com
}

Received: September 25, 2018

Accepted: November 25, $2018 \quad$ Online Published: December 4, 2018

doi:10.11114/jets.v7i1.3833

URL: https://doi.org/10.11114/jets.v7i1.3833

\begin{abstract}
This paper rests on a survey among students of Arab Open University (AOU) that covered 6,369 students from all branches (in eight countries) and across all four colleges. It endeavours to raise a case for introducing entrepreneurship education in AOU. The Survey results show a surprisingly high level of entrepreneurial intention among the students, and the overwhelming majority of them are demanding introduction of entrepreneurship education. The Paper uses results of the Survey to present how the students of AOU desire their entrepreneurship education and entrepreneurship training programmes to be organised, and to identify the target groups of each of the two programmes. Based on these results and on selected literature review of the concepts of entrepreneurship, entrepreneurship education and entrepreneurship training, an outline of entrepreneurship curricula and of teaching and training methods are suggested. Both curricula and methods advanced could be of relevance beyond the specific case of AOU.
\end{abstract}

Keywords: entrepreneurship, entrepreneurship education, entrepreneurship training, student entrepreneurship, entrepreneurship promotion, entrepreneurial intent, Arab universities

\section{Research Background, Objective and Method}

World Economic Forum (2011) tallied Arab universities that are engaged with entrepreneurship promotion (at any level). It found that less $10 \%$ deliver entrepreneurship courses, 3-4\% have established entrepreneurship centres, and about $1 \%$ offer a major in entrepreneurship. With $1 \%$ of the Arab universities offering a major, and less than $10 \%$ some courses in entrepreneurship (and these may be confined to business studies students only), Arab universities are doing too little to nurture the spirit of entrepreneurship among students; and most of their graduates leave with no skills to start own business. Moreover, with such weak capacity devoted to entrepreneurship and enterprise development they are not able to adequately address needs of their communities. Against this background, the paper aims at raising a case for introducing entrepreneurship education and training in Arab Open University (AOU) and in other Arab universities.

This paper rests on a survey among students of AOU. AOU operates in eight countries. The survey received responses from 6,369 students from all countries (branches) and across all colleges.

Based on selected literature review, a conceptual framework is developed and insights on previous international experiences in entrepreneurship education and training are gained. Built on these, outline of content of curricula and of teaching and training methods are suggested. Both curricula and methods advanced could be of wider relevance beyond the specific case of AOU, and, of course, could be developed further.

\section{Conceptual Framework}

There is agreement that entrepreneurship is necessary for economic and social development. Entrepreneurship promotion can lead to economic growth, employment creation and equity. It has also been widely accepted that entrepreneurship education and training increase entrepreneurial intention, expand the pool of nascent entrepreneurs and enhance the skills and chances of success of existing entrepreneurs.

\subsection{On Defining Entrepreneurship}

There is no precise, agreed upon, definition of entrepreneurship. Some commentators link it to innovation or to small business or to formal economic activities only, while others perceive of it as just pursuing a business opportunity (which may or may not be related to a profit organisation).

Kuratko and Hodgetts (2003) perceive of entrepreneurship as a complex process involving innovation and leadership: 'entrepreneurship is a dynamic process of vision, change, and creation. It requires an application of energy and passion 
towards the creation and implementation of new ideas and creative solutions' (p. 30).

According to Howard Stevenson, named the godfather of entrepreneurship studies at Harvard Business School, 'entrepreneurship is the pursuit of opportunity beyond resources controlled' (Eisenman, 2013). Linan et al. (2011), among others, also relate the concept of entrepreneurship to pursuance of opportunity: 'entrepreneurship- or entrepreneurial behaviour- could be defined as the discovery, evaluation and exploitation of an opportunity' (p.198).

Unlike Klapper et al. (2010), who understand entrepreneurship as a process of creating new wealth, but only in formal enterprises, Valerio et al. (2014) propose a definition that considers both formal and informal economic activities, including self-employment. Ivancevich in 1991, cited Gorman et al. (1997), contends that entrepreneurship is a 'mechanism to enhance entrepreneurial behaviours and to bridge the gaps between the functional areas' (p. 6).

Thurik and Wennekers (2004) argue that small business and entrepreneurship are related but not synonymous concepts. Entrepreneurship is about pursing an opportunity which can happen in both small or large enterprises and elsewhere. That entrepreneurship is not restricted only to business organisations is also shared by others. Kuratko (2004), for example, argues that an entrepreneurial perspective 'can be exhibited inside or outside an organisation, in profit or not-for-profit enterprises, and in business or non-business activities for the purpose of bringing forth creative ideas' ( $p$. 3). Such views have been propagated earlier by Gottleib and Ross in 1997, and Noll in 1993, both cited in Jones and English (2004), who assert that innovation and creativity and behavioural aspects of entrepreneurship can be applied in business, government and not-government areas of work.

Souitari et al, (2007), based on Bird, 1988, define entrepreneurial intention as 'a state of mind directing a person's attention and action towards self-employment as opposed to organisational employment' (p. 5).

Intrapreneurship is understood as applying behavioural aspects of entrepreneurship- innovation and creativity- by an employee within existing business organisation. Intrapreneurs affect positively the company's performance (Maier and Zenovia, 2011; Camelo-Ordaz et al., 2012), without taking the risk associated with the entrepreneur-owner. The risk taking translates into organisational risk (Antoncic, 2003).

For this paper, the concept of entrepreneurship is restricted to the profit organisations (including self-employment).

\subsection{On Entrepreneurship Education and Entrepreneurship Training}

Haase and Lautenschlager (2011) raise the question of whether entrepreneurship is teachable. They claim that entrepreneurial education should discontinue teaching knowledge of enterprise creation and focus on experiencing entrepreneurship. On the other side, other scholarly works argue to the contrary and assert (based on empirical research) that entrepreneurship is teachable. World Bank in 2010, cited in Valerio et al (2014), argue that when education and training systems integrate creative thinking and entrepreneurial skills into teaching methodologies, entrepreneurial mindsets can be created or enhanced. Potter in 2008, cited in Linan et al. (2010), maintains that entrepreneurial education is a key element in enhancing entrepreneurial attitudes. Hynes (1996) refers to a survey among US professors which found that $93 \%$ of them believed entrepreneurial knowledge and skills are transmittable through education. Kuratko (2004) contends that 'entrepreneurial perspective' can be developed in individuals, and the question whether entrepreneurship can be taught is obsolete; the question should be, as raised by Ronstadt in 1987, what should be taught and how should it be taught.

Entrepreneurship education and training are called for to increase supply of potential entrepreneurs (people interested in engaging in entrepreneurial activities) and of nascent entrepreneurs (people attempting to start a business venture) and to aid existing entrepreneurs to create higher performing enterprises (Hynes, 1996; Jones and English, 2004; Linan et al., 2010; Valerio et al., 2014).

Both entrepreneurial education and entrepreneurial training aim at stimulating entrepreneurship (Valerio, 2014). However, in terms of some content and orientation of programme and the targeted groups, they exhibit differences. Entrepreneurial education is building knowledge, values (mindsets) and skills that are not related to a narrow field of activity. The aim is to raise awareness about entrepreneurship as a career option and increase the pool of potential entrepreneurs. Education can be formal or informal and normally organised at secondary and/or higher education levels. Entrepreneurial training is a more systematic and planned effort to build knowledge and skills through learning experiences among potential entrepreneurs for the purpose of starting a business or among existing entrepreneurs with the aim of improving existing enterprise performance (Hynes, 1996; Valerio et al., 2014).

Figure 1 illustrates target groups of entrepreneurship education and entrepreneurship training. A note is to be made on the categories of subsistence and accumulation entrepreneurs. Subsistence entrepreneurs are those seeking to establish, or owners of micro or small enterprises (including self-employed) working in formal or informal activities, whose motive is to secure subsistence.. Accumulation entrepreneurs are those seeking to start or own a business with the aim of growth. (This last group is present among AOU students as is shown in the coming section). 

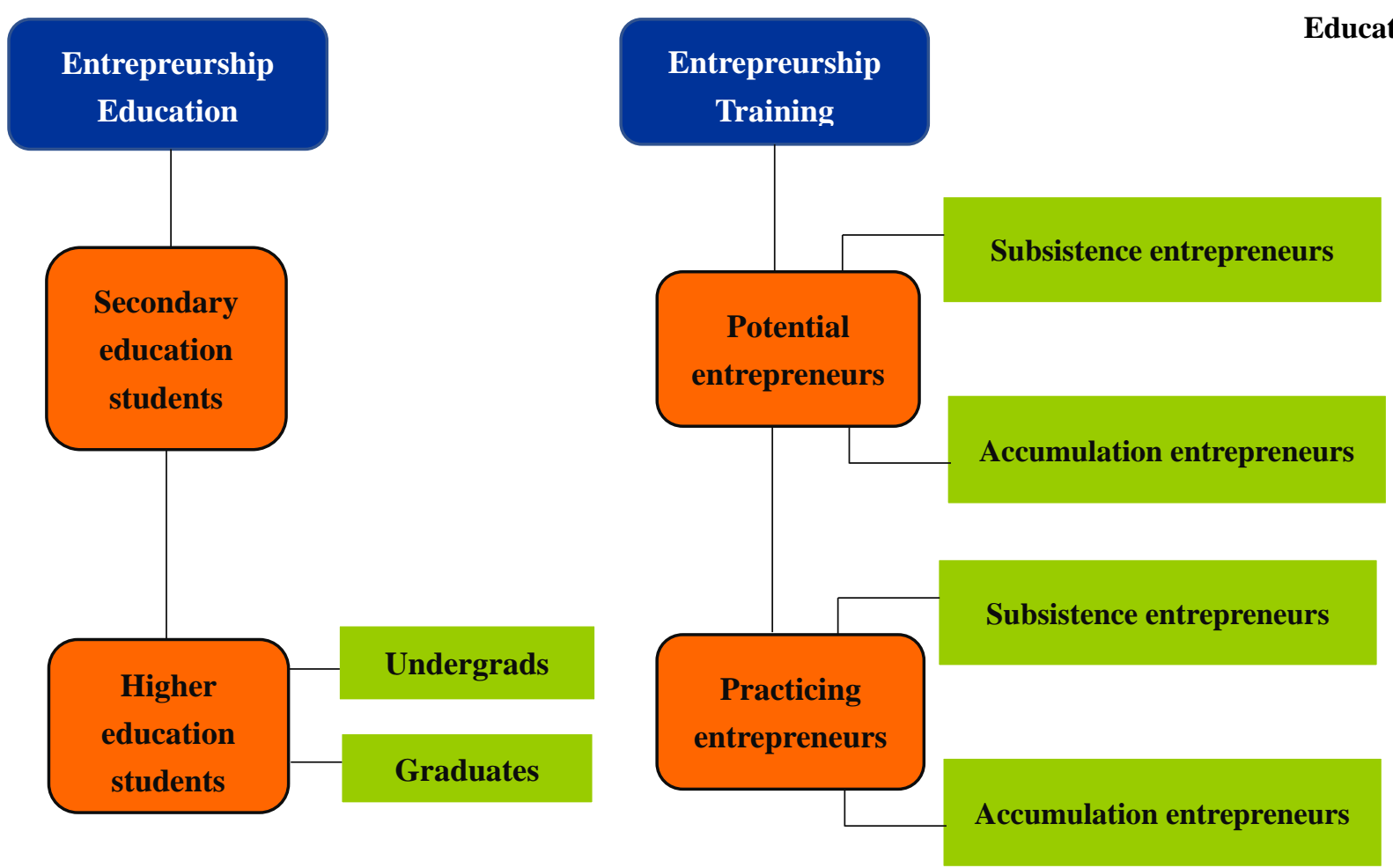

Figure 1. Target Groups of Entrepreneurship Education and Entrepreneurship Training

Adapted from Valerio et al. (2014)

\subsection{Management Education versus Entrepreneurship Education and Training}

The concern of both management education and entrepreneurship education and training is enterprise management and development. While there are common areas of knowledge and skills, there are differences in the components and methods of acquiring the range of knowledge and skills (Valerio et al., 2014).

Business education trains students to operate within existing hierarchies of enterprises (Sexton and Bowman, 1984, cited in Valerio et al, 2014); it nurtures the follower and the steward over the creator and the risk bearer (Chia, 1996, cited in Jones and English, 2004). Porter in 1994, cited, again, in Jones and English (2004) maintains that entrepreneurship education focuses on creativity and risk taking whereas traditional management education emphasises quantitative and corporate techniques. Garavan and O'Cinneide (1994) contend that 'while every career in business involves some combination of knowledge, technique and people skills, few involve the integration and combination of all functional knowledge and skills to the extent that entrepreneurial activities does' (p.5). They add that major attributes of entrepreneurs are three: knowledge, skills and attitudes. The first can be dealt with thoroughly in business schools, the second is challenging to impart (fully) within formal educational systems, and the third hardly receives any attention.

Skills taught in management schools are required by entrepreneurs as well, but management students learn how to manage some important functions of the enterprise while entrepreneurship education addresses the unique conditions that entrepreneurs face (Jones and English, 2004; Valerio, 2014).

\section{A Framework of Entrepreneurship Education and Entrepreneurship Training Programmes: Learning Form the Literature}

\subsection{On Content}

Entrepreneurship education and entrepreneurial training furnish students and trainees with capabilities (knowledge, skills and mindsets) in three major arenas: 1-recongnising opportunities, 2- mobilising resources, and 3- creating, sustaining and developing the enterprise (Kourilsky in 1995, and Gottleib and Ross in 1997, cited in Jones and English, 2004).

Citing many other commentators, Valerio et al. (2014) list common knowledge, skills and mindsets of entrepreneurial education and training as; 'socio-emotional skills like self-confidence, leadership, creativity, risk propensity, motivation, resilience and self-efficacy; overall awareness and perception of entrepreneurship; and the general business knowledge 
and skills needed for opening and managing a business, like accounting, marketing, risk assessment and resource mobilisation' (p. 22). Additionally, 'some entrepreneurial training programmes target specific technical knowledge or skills associated with a particular occupation or a sector' (p. 38).

Johannisson in 1991, cited in Gorman et al. (1997), perceives four bases of entrepreneurship; 'an ability to impact one's personal environment, a high degree of self-confidence, an ability to create support networks, and an ability to create linkage from vision to action' (p. 10). Examining emphasis on each of these dimensions, Johannisson surveyed Swedish universities and the conclusion was that universities emphasise the technical aspects to the extent that may discourage potential entrepreneurs.

Citing Hisrich and Peters in 1988, Lekoko et al (2012) include in the content of entrepreneurship education the following skills. 1- Technical skills: organising managing and communication skills; 2- Personal entrepreneurial skills: attributes such as risk taking and creativity; 3 - Business management skills: like marketing, accounting and decisionmaking. Acquiring these skills may enhance self-efficacy among the students.

In an evaluation of ten higher education entrepreneurship programmes, Valerio et al. (2014) found that the programmes imparted knowledge of general business education, marketing and accounting. Several of them provided knowledge and skills on preparation of business plan and strategy to develop the enterprise. Some ended with mentoring and coaching given by entrepreneurs.

Based on reviewing literature and a search of offerings in some major universities, Souitaris, et al. (2007) note that entrepreneurship programmes include a portfolio of activities: 1- taught component, 2- business-planning component, 3interaction with practice component, and 4- university resources component (research resources, space, for meetings etc.)

\subsection{On Methods}

Hynes (1996) asserts that 'entrepreneurship education needs to avoid the mechanistic approach of business teaching, which often conveys the image of business as being about systems or techniques and ignore the motivation and personal competency components which are essential for enterprise development' (p. 11)

Gibb in 2002, cited in Jones and English (2004), maintains that entrepreneurship education needs a different teaching environment in universities. Jones and English (2004) consider such environment as one that facilitates 'a teaching style that is action oriented, encourages experiential learning, problem solving, project-based learning, creativity and is supportive of peer evaluation' (p. 416). They, however, acknowledge that departing from traditional university lecture-based style may be difficult in some disciplines that entrepreneurship education also requires, such as accounting, marketing and information systems.

Citing many others, Baptista and Naia (2015) list the following methods used in entrepreneurship education and training: 'case studies; reading; interviews with entrepreneurs; class discussion, business visits and field trips; internships and working with entrepreneurs; and development of business start-ups' (p. 3). Additionally, use of technology and computer-based simulations are increasing.

Hynes (1996) contends that entrepreneurship education combines formal and informal methods, and the choice of delivery will depend on the student group. The author identifies three methods:

1-Didactic Method. This formal method is used to impart theoretical and conceptual frameworks that support understanding entrepreneurship knowledge (cognitive objectives of the programme). Lectures, seminars, readings are used to convey new information from which students learn how to analyse and interpret data.

2- Skills Building Method. This informal aspect of entrepreneurial education focuses on attribute development and behavioural change; reinforcing existing skills and develop new ones. Methods used are active case studies and group discussions.

3- Discovery Method. Informal method based on experiential learning that allows students to learn solving problems and developing actions in real world situations. Contact with entrepreneurs and external organisations facilitate learning and develop networks.

\section{How AOU Students Want Entrepreneurship Education and Training to Be Organised?}

A survey was conducted among AOU students in 2016 to assess student entrepreneurial intention and whether and how they want entrepreneurship education and training to be introduced at the University. A total of 6,369 students responded from all eight branches (Bahrain, Egypt, Jordan, Oman, Kuwait, Lebanon, Saudi Arabia -KSA- and Sudan) and the four colleges within them (Business Studies, Computer Studies and IT, Education, and Languages). The response rate was $22.4 \%$ of all the students registered at the time of conducting the survey. According to the Learning Management System's supervisor, this has been the highest response rate ever received for any questionnaire 
administered through the system. The survey tool was a close-ended questionnaire composed of 12 questions, together with a short message explaining the purpose. The questionnaire was placed in the University's Learning Management System for a period of six weeks (May-June 2016). It was meant to be short (answerable in a period of 5-8 minutes) to encourage wider participation.

The results of the survey show a surprisingly high level of entrepreneurial intention among the students, and the overwhelming majority is demanding introduction of entrepreneurial education. The strong level of entrepreneurial intention has spread across all branches (a range of $75.6 \%$ to $83.5 \%$ ) and colleges (a range of $69.4 \%$ to $83.1 \%$; Business studies being the highest) and was strongly evident among both genders ( $75.7 \%$ female and $82.0 \%$ male). The average intention rate of $78.2 \%$ exceeds by far the average of adults who have a positive perception about starting a business in the GEM 2017/18 Global Report (GEM, 2018), where Factor Driven economies registered 30.3\%, Efficiency Driven, $36.3 \%$ and Innovation Driven economies, 15.2\%. (Analysis of the entrepreneurial intention among AOU students is provided in another paper).

The respondents were asked whether they thought it would be a good idea to introduce entrepreneurship education/training programmes at the University. As Table 1 shows, $92.4 \%$ of the students were in support. By college, Business Studies scored 94.3\%, Education: 87.8\%, Language Studies: 89.2\%, and Computer Studies: 92.8. It is interesting to note that students of Business Studies, who scored highest for 'yes' to introducing entrepreneurship education, seem to realise that management education, which they follow, is different from entrepreneurship education.

Table 1. Do you Think it is a Good idea if the University Organises Entrepreneurship Education/Training Programmes?

\begin{tabular}{lccc}
\hline & Responses & Frequency & Percent \\
Yes & & 5882 & $92.4 \%$ \\
No & & 141 & $2.2 \%$ \\
I don't know & & 346 & $5.4 \%$ \\
& Total & $\mathbf{6 3 6 9}$ & $\mathbf{1 0 0 \%}$
\end{tabular}

Respondents who answered 'yes' to the question in Table 1 were asked further as to how they want entrepreneurship education/training to be organised. Responses are given in Table 2, 3, and 4, by branch, gender and college, respectively.

Table 2. Student Preference for Provision of Entrepreneurship Education-By Branch

\section{Branch Name}

Should it be provided:

1-Within your courses of studies?

2 As separate training only for those who wish to receive it, and who can earn certificates of completion?

3-Both within the courses and as additional separate advanced certified training?

\begin{tabular}{|c|c|c|c|c|c|c|c|c|}
\hline 㞼 & 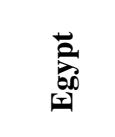 & 苞 & ڤี & 萢 & 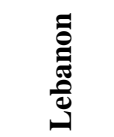 & $\mathbb{4}$ & $\stackrel{\Xi}{\overparen{E}}$ & Total \\
\hline $\begin{array}{c}28 \\
9.9 \%)\end{array}$ & $\begin{array}{c}67 \\
(10.0 \%)\end{array}$ & $\begin{array}{c}208 \\
(16.4 \%)\end{array}$ & $\begin{array}{c}28 \\
(16.3 \%)\end{array}$ & $\begin{array}{c}75 \\
(8.9 \%)\end{array}$ & $\begin{array}{c}34 \\
(9.1 \%)\end{array}$ & $\begin{array}{c}189 \\
(8.5 \%)\end{array}$ & $\begin{array}{c}6 \\
(14.6 \%)\end{array}$ & $\begin{array}{c}635 \\
(10.8 \%)\end{array}$ \\
\hline $\begin{array}{l}149 \\
2.5 \%)\end{array}$ & $\begin{array}{c}255 \\
(38.0 \%)\end{array}$ & $\begin{array}{c}545 \\
(42.9 \%)\end{array}$ & $\begin{array}{c}81 \\
(47.1 \%)\end{array}$ & $\begin{array}{c}391 \\
(46.2 \%)\end{array}$ & $\begin{array}{c}189 \\
(50.8 \%)\end{array}$ & $\begin{array}{c}1036 \\
(46.6 \%)\end{array}$ & $\begin{array}{c}16 \\
(39.0 \%)\end{array}$ & $\begin{array}{c}2662 \\
(45.3 \%)\end{array}$ \\
\hline $\begin{array}{l}107 \\
37.7 \%)\end{array}$ & $\begin{array}{c}349 \\
(52.0 \%)\end{array}$ & $\begin{array}{c}518 \\
(40.8 \%)\end{array}$ & $\begin{array}{c}63 \\
(36.6 \%)\end{array}$ & $\begin{array}{c}380 \\
(44.9 \%)\end{array}$ & $\begin{array}{c}149 \\
(40.1 \%)\end{array}$ & $\begin{array}{c}1000 \\
(44.9 \%)\end{array}$ & $\begin{array}{c}19 \\
(46.3 \%)\end{array}$ & $\begin{array}{c}2585 \\
(43.9 \%)\end{array}$ \\
\hline $\begin{array}{l}284 \\
100 \%)\end{array}$ & $\begin{array}{c}671 \\
(100 \%)\end{array}$ & $\begin{array}{c}1271 \\
(100 \%)\end{array}$ & $\begin{array}{c}172 \\
(100 \%)\end{array}$ & $\begin{array}{c}846 \\
(100 \%)\end{array}$ & $\begin{array}{c}372 \\
(100 \%)\end{array}$ & $\begin{array}{c}2225 \\
(100 \%)\end{array}$ & $\begin{array}{c}41 \\
(100 \%)\end{array}$ & $\begin{array}{c}5882 \\
(100 \%)\end{array}$ \\
\hline
\end{tabular}


Table 3. Student Preference for Provision of Entrepreneurship Education- By Gender

\begin{tabular}{|c|c|c|c|}
\hline \multirow{2}{*}{ Should it be provided: } & \multicolumn{2}{|c|}{ Gender } & \multirow{2}{*}{ Total } \\
\hline & Male & Female & \\
\hline \multirow{2}{*}{ 1-Within your courses of studies? } & 327 & 308 & 635 \\
\hline & $(13.3 \%)$ & $(9.0 \%)$ & $(10.8 \%)$ \\
\hline \multirow{2}{*}{$\begin{array}{l}\text { 2-As separate training only for those who wish to receive it, and who can earn certificates } \\
\text { of completion? }\end{array}$} & 1118 & 1544 & 2662 \\
\hline & $(45.4 \%)$ & $(45.2 \%)$ & $(45.3 \%)$ \\
\hline \multirow{2}{*}{ 3-Both within the courses and as additional separate advanced certified training? } & 1020 & 1565 & 2585 \\
\hline & $(41.4 \%)$ & $(45.8 \%)$ & $(43.9 \%)$ \\
\hline \multirow[t]{2}{*}{ Total } & 2465 & 3417 & 5882 \\
\hline & $(100 \%)$ & $(100 \%)$ & $(100 \%)$ \\
\hline
\end{tabular}

Table 4. Student Preference for Provision of Entrepreneurship Education- By College

\begin{tabular}{lccccc}
\hline \multicolumn{1}{c}{ Should it be provided: } & $\begin{array}{c}\text { College of Enrolment } \\
\text { Business } \\
\text { Studies }\end{array}$ & Education & $\begin{array}{c}\text { Language } \\
\text { Studies }\end{array}$ & $\begin{array}{c}\text { Computer } \\
\text { Studies and IT }\end{array}$ & Total \\
\hline 1-Within your courses of studies? & 299 & 112 & 79 & 145 & 635 \\
& $(10.6 \%)$ & $(16.6 \%)$ & $(9.5 \%)$ & $(9.3 \%)$ & $(10.8 \%)$ \\
$\begin{array}{l}\text { 2-As separate training only for those who wish } \\
\text { to receive it, and who can earn certificates of }\end{array}$ & 1236 & 314 & 408 & 704 & 2662 \\
completion? & $(43.8 \%)$ & $(46.5 \%)$ & $(49.0 \%)$ & $(45.3 \%)$ & $(45.3 \%)$ \\
3-Both within the courses and as additional & 1287 & 249 & 345 & 704 & 2585 \\
separate advanced certified training? & $(45.6 \%)$ & $(36.9 \%)$ & $(41.5 \%)$ & $(45.3 \%)$ & $(43.9 \%)$ \\
\multicolumn{1}{c}{ Total } & $\mathbf{2 8 2 2}$ & $\mathbf{6 7 5}$ & $\mathbf{8 3 2}$ & $\mathbf{1 5 5 3}$ & $\mathbf{5 8 8 2}$ \\
& $\mathbf{( 1 0 0 \% )}$ & $\mathbf{( 1 0 0 \% )}$ & $\mathbf{( 1 0 0 \% )}$ & $\mathbf{( 1 0 0 \% )}$ & $\mathbf{( 1 0 0 \% )}$
\end{tabular}

Student preference for the provision of a programme on entrepreneurship is clearly not only within their courses of studies; on average only $10.8 \%$ of all respondents chose this option. The overwhelming majority prefer the programme to be offered as a separate certified training (45.3\%) or both within the courses and as separate advanced certified training $(43.9 \%)$. Such a trend prevailed among all branches, colleges and the two sexes.

Table 5 exhibits the relative standard deviation of provision preference at all three levels of analysis. The results suggest that there will be no need to design separate forms of organisation of provision for branches or for colleges or by gender.

Table 5. Relative Standard Deviation of Student Preference for Provision of Entrepreneurship Education/Training

Should such training be provided:

1-Within your courses of studies?

2-As separate training only for those who wish to receive it, and who can earn certificates of completion?

3-Both within the courses and as additional separate advanced certified training?

$\begin{array}{ccc}\text { Branch } & \text { Gender } & \text { College } \\ 3.4 \% & 3.0 \% & 3.4 \% \\ 5.2 \% & 0.1 \% & 2.2 \% \\ 5.1 \% & 3.1 \% & 4.1 \%\end{array}$

\section{Target Groups and Structure of Entrepreneurship Education and of Entrepreneurship Training}

Entrepreneurship education aims at raising awareness, imparting knowledge and skills, developing mindsets and motivating students to choose entrepreneurship as a career, in addition to other benefits even if it is not chosen, or will not become feasible as a career. It targets all undergraduate and postgraduate students in all branches and colleges (as indicated in figure 1 above).

Entrepreneurship training aims at developing knowledge of, and imparting skills to potential entrepreneurs (to move them from desirability to feasibility) and enhancing performance of existing entrepreneurs. While entrepreneurship 
training is not normally provided in universities for students, in AOU it seems to be a necessity. AOU attracts working students and students with prior working experience: $53.9 \%$ of all the students, as per results of the Survey. Among AOU students $20.8 \%$ are either current (co-) owners of business or were previously so, and among these two categories, $89.3 \%$ still aspire to continue managing their businesses or explore new opportunities. They are the categories of potential and practising entrepreneurs indicated in Figure 1 above, who may not require awareness about entrepreneurship with the aim of choosing it as a career, as they have already done so, but they need extra knowledge and skills to start new businesses or improve performance of their existing enterprises.

\subsection{Building the Base of Entrepreneurship Education}

Undergraduate and postgraduate students who are not currently, or were not in the past, owners of businesses will be the target of entrepreneurship education. Those who have business experience will receive special entrepreneurship training.

The base of the curriculum structure signifies the move from desirability (entrepreneurship awareness) to feasibility (mindset, knowledge and skills leading to self-efficacy) and, then, to starting a business. Four curricula domains are proposed. Content and delivery methods are based on what has been discussed above and draw on Jones and English (2004) and Hynes (1996).

The first domain focuses on defining entrepreneurship. In this domain, the following topics may be covered: concept and value of entrepreneurship and characteristics of entrepreneurs; entrepreneurial and ethical self-assessment, creativity and innovation skills and intrapreneurship. Information about entrepreneurship and small business situation in the country (economic contribution, challenges, support organisations, etc.) is to come under this domain. The second domain concentrates on recognising opportunities. Here, knowledge and skills on idea generation, evaluating ideas and innovation and new product/service development are to be imparted. In the third domain, mobilising resources-related topics are taught. These include, financial literacy, opportunities of financing a start-up or a newly acquired business, applying for finance, and mobilising human and other non-financial resources. Creating and operating the enterprise makes the fourth and the largest curriculum domain. In this domain, students acquire a wide variety of management skills: people's management, teamwork, marketing, sales and financial management. After being acquainted with business regulations, the students learn how to, and make a business strategy and a plan. Deployment and implementation of business strategy/plan require different set of skills, including, but not limited to, negotiations and deal making. Skills of analysis of business situation and of minimising business failure are important for the process of making and implementing the plan. Culmination of the entrepreneurship education programme can take the form of a few wrap-around activities, like business plan competitions, networking events, access to mentoring, coaching and finance.

It is to be noted that the domains described above do not (necessarily) translate into single courses. Bearing in mind students' preference of organisation of entrepreneurial education, it is proposed that Domains 1 and 2 (which signify the move from desirability to feasibility) are to be offered within the existing programme structure as part of the General Requirement courses. Domains 3 and 4, for which Domain 1 and 2 will be perquisites, can be offered as electives and as separately certified programmes.

The three methods identified by Hynes (1996) - didactic, skills building and discovery methods- could be ideal for entrepreneurship education. The functional knowledge and skills imparted are integrated within the mind of and used by one and the same person. This would require close coordination to ensure integration and complementarity of content and method of delivery of the different domains.

\subsection{Building the Base of Entrepreneurship Training}

This programme, as has been indicated, targets those students who have business experience (20.8\% of total), and it can be opened to graduates and other members of the community. Participants in entrepreneurship training are either embarking on a new project or intending to enhance performance.

Entrepreneurship training programme differs from entrepreneurial education programme in two major ways: the target group is already aware of value of entrepreneurship, and programme content focuses on knowledge, skills and attitude related to a specific sector or occupation group. Hence, trainees are to be grouped accordingly (e.g. IT service, retail, etc.).

The first training domain is financial management and planning. Depending on background of trainees, it can be organised at two levels (e.g. basic and intermediate). Both are to have a component of cash flow management and planning, basic techniques of preparing a project for funding, and of sources of funding. In the second domain, training is provided on managing non-financial operations: people, production/service provision, marketing, sales and procurement. The third domain may be labelled as evaluation, innovation and development planning. In this 
domain, trainees are to develop knowledge and skills that are necessary for screening and evaluating business ideas and conducting project feasibility study, innovation in production or service provision, and planning for strategic change and development. Risk assessment techniques (financial, production and market risks) make the fourth domain of training, and the wrap-around activities (networking, also to explore funding and technical assistance opportunities, and mentoring and coaching by entrepreneurs and consultants) is the last on the list of the training programme.

Trainees learn through demonstration, practice and feedback. Hence, the discovery method would be the main training method.

The group of students with current or previous business experience may need to be researched further with the view of assessing their level of experience and the specific activities of their current or future businesses. This will be expedient for designing the training programmes that suit each of the subgroups

\subsection{Evaluation of Outcomes of Programmes}

The main method used for evaluating outcomes of entrepreneurial education programmes is to assess change in mindsets and level of knowledge and skills acquired by the students in an absolute measure; that is before and after taking the programme, and in a relative sense; compared with those who have not been exposed to the programmes.

Outcomes of entrepreneurial training programmes can be measured through the rate of new business ventures started by those participants seeking to open new businesses and measuring performance improvement by those whose objective is to improve performance of existing enterprises. For the latter, the best is to assess change in income. It is also possible, especially immediately after the programme when no felt of income change has occurred, to base the evaluation on trainees' opinions. Henry et al. (2005) offer elaborate consideration of methods of outcome evaluation of entrepreneurship programmes and argues for the need of cost-benefit analysis in these evaluations.

\section{Concluding Notes}

Universities generally, and public universities specifically, have responsibility to address socioeconomic development challenges in their countries. Poverty and unemployment constitute two of the major challenges in most of the Arab countries. Not only that universities need to prepare employable graduates, including with entrepreneurial skills, but they should also engage with their communities to alleviate poverty and create employment opportunities through community-oriented/engaged training and research for entrepreneurship development, among other developmental efforts.

In addition to satisfying needs of potential and practicing entrepreneurs among the students, entrepreneurship training programme can be opened to the community. This, from one side, enhances the University community engagement role, and from another, brings potential and practising entrepreneurs from outside the University, with diversified experiences, who may enrich the learning experiences of AOU students.

Developing curricula for entrepreneurship education and training may not need to start from scratch. Many universities and specialist organisations round the world have developed entrepreneurship teaching and training programmes and materials. Institutions of higher education, or any other organisation, may draw on these experiences and then tailor-make the content and method of delivery of the programmes in accordance with the (beforehand- assessed) needs of their target group.

\section{References}

Antoncic, B. (2003.) Risk Taking in Intrapreneurship: Translating the Individual Level Risk Aversion into the Organizational Risk Taking. J. Enterprising Culture, 11(1), 1-23. https://doi.org/10.1142/S0218495803000020

Baptista, R., \& Naia, A. (2015). Entrepreneurship Education: A Selective Examination of the Literature. Foundations and Trends in Entrepreneurship, 11(5), 337-426. https://doi.org/10.1561/0300000047

Bird, B., Implementing Entrepreneurial ideas: The Case for Intention (1988). Academy of Management Review, 3(3), 442-453. https://doi.org/10.5465/amr.1988.4306970

Camelo-Ordaz, C., Fernández-Alles, M., José Ruiz-Navarro, J., \& Sousa-Ginel, E. (2012). The intrapreneur and innovation in creative firms. International Small Business Journal, 30(5), 511-537. https://doi.org/10.1177/0266242610385396

Eisenmann, T. (2013). What is entrepreneurship? Harvard Business Review, 3 January, 2013. https://hbr.org/2013/01/what-is-entrepreneurship.

Garavan, T., \& O’Cinneida, B. (1994). Entrepreneurship Education and Training Programmes: A Review and EvaluationPart 1. Journal of European Industrial Training, 18(8), 3-12. https://doi.org/10.1108/03090599410068024 
GEM-Global Entrepreneurship Monitor (2018), GEM 2017/18 Global report. https://www.gemconsortium.org/report/50012

Gorman, G., Hanlon, D., \& King, W. (1997). Some Research Perspectives on Entrepreneurship Education, Enterprise Education and Education for Small Business Management: A Ten-Year Literature Review. International Small Business Journal, 15(3), 56-77. https://doi.org/10.1177/0266242697153004

Haase, H., \& Lautenschlager, A. (2011). The Teachability Dilemma of Entrepreneurship. International Entrepreneurship and Management Journal, 7(2), 145-162. https://doi.org/10.1007/s11365-010-0150-3

Henry, C., Hill, F., \& Leitch, C. (2005). Entrepreneurship education and training: can entrepreneurship be taught? Part II. Education + Training, 47(3), 158-169. https://doi.org/10.1108/00400910510592211

Hynes, B. (1996). Entrepreneurship education and training - introducing entrepreneurship into non-business discipline. Journal of European Industrial Training, 20(8), 10-17. https://doi.org/10.1108/03090599610128836

Jones, S., \& English, J. (2004). A contemporary approach entrepreneurship education. Education + Training, 46(8/9), 416-423. https://doi.org/10.1108/00400910410569533

Klapper, L., Amit, R., \& Guillén, M. F. (2010). Entrepreneurship and Firm Formation across Countries', in Lerner, J and Scoar, A. (eds), International Differences in Entrepreneurship, University of Chicago Press, 129-158. https://doi.org/10.7208/chicago/9780226473109.003.0005

Kuratko, D. (2004). Entrepreneurship Education In The 21st Century: from Legitimization to Leadership, A Coleman Foundation White Paper, USASBE National Conference, January 16, 2004. https://pdfs.semanticscholar.org/d89d/3a2a96b5c645ab42b0e28f6d73be7f961fe6.pdf

Kuratko, D., \& Hodgetts. R. (2003). Entrepreneurship: Theory, Process, and Practice, South- Cincinnati OH (USA): Western College Publisher.

Lekoko, M., Rankhumise, M., \& Ras, P. (2012). The effectiveness of entrepreneurship education: What matters most? African Journal of business Management, 6(51), 12023-12033. https://doi.org/10.5897/AJBMx12.001

Linan, F., Rodrigues-Cohard, J., \& Rueda-Cantuche, J. (2010). Factors affecting entrepreneurial level: a role for education. International Entrepreneurship Management Journal, (7), 195-218.

Maier, V., \& Zenovia, C. (2011). Entrepreneurship versus Intrapreneurship. Review of International Comparative Management, 12(5), 971-976.

Souitaris, V., Zerbinati, S., \& Al-Laham, A. (2007). Do entrepreneurship programmes raise entrepreneurial intention of science and engineering students? The effect of learning, inspiration, and resources, Journal of Business Venturing, 22(4), 566-591. https://doi.org/10.1016/j.jbusvent.2006.05.002

Thurik, R., \& Wennekers, S. (2004). Entrepreneurship, small business and economic growth. Journal of Small Business and Enterprise Development, 11(1), 140-149. https://doi.org/10.1108/14626000410519173

Valerio, A., Parton, B., \& Robb, A. (2014). Entrepreneurship Education and Training Programs around the World, Washington D.C: The World Bank. https://openknowledge.worldbank.org/bitstream/handle/10986/18031/9781464802027.pdf

World Economic Forum (2011). Accelerating Entrepreneurship in the Arab World, Cologny (Switzerland): World Economic Forum.

\section{Copyrights}

Copyright for this article is retained by the author(s), with first publication rights granted to the journal.

This is an open-access article distributed under the terms and conditions of the Creative Commons Attribution license which permits unrestricted use, distribution, and reproduction in any medium, provided the original work is properly cited. 